\title{
Nutritional Properties of Tamarind (Tamarindus indica) Kernel Flour
}

\author{
Gitanjali $^{1 *}$, Vishakha Sharma ${ }^{2}$ and Shashi Jain ${ }^{2}$ \\ ${ }^{1}$ Department of Food and Nutrition, College of Community Science, Dr. Rajendra Prasad \\ Central Agricultural University, Pusa, Samastipur, Bihar 848125, India \\ ${ }^{2}$ Department of Food Science and Nutrition, College of Community and Applied Science, \\ Maharana Pratap Agricultural University and Technology, Udaipur, Rajasthan 313001, India \\ *Corresponding author
}

\section{A B S T R A C T}

\begin{tabular}{|l|}
\hline Ke y w o r d s \\
Tamarind kernel \\
flour Proximate \\
composition, \\
Mineral
\end{tabular}

\begin{abstract}
The aim of the study was to investigate the proximate composition and mineral content of tamarind (Tamarindus indica) kernel flour, which were processed by roasting at $150 \mathrm{oC}$ for $15 \mathrm{~min}$ to remove the seed coats. The proximate analysis of the tamarind kernel flour revealed the values of moisture, ash, fat, crude protein, crude fiber, and total carbohydrate contents present to be $7.65 \%, 2.74 \%, 5.7 \%, 19.46 \%, 2.32 \%$ and $62.13 \%$ respectively. The minerals present were calcium (109.25), Magnesium (247.51), iron (11.37) and potassium (1245.11) for the flour in $\mathrm{mg} / 100 \mathrm{~g}$. The result indicated that tamarind kernel flour has good nutritional profile and can play significant roles in the diet of people.
\end{abstract}

\section{Introduction}

Tamarind (Tamarindus indica L), a member of the family Leguminosae (Fabaceae), is native to dry Savanna of tropical Africa (Mohamed, et al., 2015). The major areas of production are in Asian countries like India, Bangladesh, SriLanka, Thailand. India is the main producer and consumer of tamarind in the world (Havinga et al., 2010). Tamarind is a multipurpose tree species; almost every part of it finds some use. The fruit contains about pulp (55.0\%), seed (34.0\%) and shell $(11.0 \%)$, and the fiber in a pod (Kumar and Bhattacharya, 2008).

It is cultivated mainly for its fruit pulp, which is used to prepare a beverages and to flavour confection, curries and sauces and accepted as herbal medicine in many parts of the world. The tamarind seeds are very hard, shiny, reddish, or purplish brown. The kernel of 
tamarind has flat surface, random texture, less round, oval or dull square. Tamarind kernel can resistant for several months when it is saved in dry place. Tamarind seed is an underutilized by product of the tamarind pulp industry. Only a small portion of the seed, in the form of tamarind kernel powder is used as a sizing material in the textile, paper, and jute industries. Tamarind powder functions as material in cake or bread processing. Now these days, people use tamarind powder to coagulate fruit juice, to replace starch in textile maintenance treatment, and to medicate ulcer. The excellent gelling cum adhesive characteristics of the decorticated seed powder can lead to several applications in food, cosmetics and pharmaceutical industries (Pugalendhi et al., 2007).

In India, the seeds are roasted, seed coats are removed mechanically, and dehulled tamarind seed are soaked overnight in the water and eaten with the addition of salt/ sugar by the rural people/ certain ethenic groups such as Malayali and Dravidian tribes. Flower and leaves of tamarind are eaten as vegetables and the gum obtained from the seed is used for manufacturing tamarind gum and has been added to many kinds of foods in japan to improve their viscosity (Linda et al., 2014 and Khairunnur et al., 2009). Further the low cost tamarind kernel powder could be used as good substitute for costly pectin for making jelly (Pugallenthi and Vadivel, 2007).

Tamarind kernel is a kind of waste that is not yet used optimally. As natural hydrocolloid source, for it is containing starch and gum, the kernel can be changed in powder form to increase its utility. In powder processing, kernel shell must be separated. Testa separation from tamarind kernel is very important part in tamarind kernel powder processing. It is because tamarind kernel testa causes to depression and disgetion disturbance (Havinga et al., 2010).
Despite the desirable nutritional features, tamarind seeds are not extensively utilized as food/ feed mainly due to presence of certain antinutritional compounds such as total phenols, tannins and phytic acids. Since, major antinutrients present mostly in the seed coats, the removal of seed coat will be a fruitful approach for the utilisation of tamarind.

The intrinsic value of raw tamarind can be further enhanced through value addition activities and there is a good market for these processed products both in the domestic as well as in international circuits( Siddig et al., 2006; and Siddharaju, 2007). The proper use of the seed may fetch better return to the pulp processing industries that in turn may help the people who gather or even cultivate the tree. Although, few reports are available on the nutritional value of tamarind kaernel. Keeping all these benefits in mind, present study was planned to determine the nutritional composition of tamarind kernel.

\section{Materials and Methods}

Tamarind seeds were procured in a single lot from the local market of Udaipur city. All the seeds were sorted to remove rotten seeds, debris, stones, dirt and the bad seeds and keeping the good seeds. These seeds were washed, dried and roasted in oven toaster cum griller at a temperature of $150^{\circ} \mathrm{C}$ for $15 \mathrm{~min}$. Seed coat of roasted tamarind kernel was separated with the help of mortar and pestle and grounded into fine flour in an electrical grinder.

The tamarind kernel flour thus obtained were sieved through a 60 mesh sieve and packed in airtight plastic containers for further nutritional analysis (Fig-1). The nutritional characteristics of tamarind kernel flour were analyzed in the laboratory using the standard procedures (AOAC, 2000). 
The nutrients such as moisture, carbohydrate, crude protein, ash content, fat and crude fibre content were analyzed. All the estimation was done in triplicates. The standard methods described below were followed.

\section{Proximate composition}

\section{Moisture content}

Moisture content was analyzed using hot-air oven method (AOAC, 2000).

\section{Crude protein}

Crude protein was estimated by standard method (Micro Kjaldhal method) of analysis (AOAC, 2000), using KEL PLUS Automatic Nitrogen Estimation System.

\section{Ash content}

Ash in the sample was estimated by employing the standard method of analysis (AOAC, 2000)

\section{Fat}

Fat was estimated by employing the standard method of analysis (AOAC, 2000) using the Automatic SOCS plus Solvent Extraction System using petroleum ether as solvent.

\section{Crude fiber}

Crude fibre was estimated by employing the standard method of analysis (AOAC, 2000) using Automatic Fibra plus system.

\section{Total carbohydrate}

Amount of total carbohydrate was calculated from the sum of moisture, crude protein, crude fat, ash and crude fibre and lastly subtracting it from 100.

\section{Mineral content}

Tamarind kernel flour was digested by the wet digestion method. One gram of the dried and powdered sample was dissolved in $5 \mathrm{ml}$ of concentrated nitric acid, added $5 \mathrm{ml}$ of 70 percent per chloric acid and digested till a colourless or a slightly greenish solution was obtained. The digested sample was transferred into a $100 \mathrm{ml}$ volumetric flask and made to the volume with distilled water (Duhan et al., 2002). These samples were then loaded to Atomic Absorption Spectrophotometer and concentration of elements was estimated. In the present investigation, mineral elements i.e. calcium, iron, magnesium and potassium contents were analyzed using atomic absorption spectrophotometer (ECIL, model AAS 4141).

\section{Results and Discussion}

\section{Proximate composition of tamarind kernel} flour

Table-1 showed that the moisture content and ash content of tamarind kernel flour was 7.65 and 2.74 percent, respectively. The fat and crude protein content of flour was found 5.7 and 19.46 percent, respectively.

The proximate principle of tamarind seed kernel (Figure -2) revealed that the crude protein content $(19.46 \%)$ was found to be higher, since moderate intake of these seeds will greatly increase the total dietary protein intake of the people. This results supported by Caluw et al., (2010) and Khairunnuur et al., (2009) reporting tamarind kernel contains high protein (18.4-26.9\%) and lipids (5.4$10.9 \%$ ) and other nutrients with good nutritional quality. The crude fibre and total carbohydrate content were found 2.32 percent and 62.13 percent respectively. The carbohydrate content of tamarind kernel flour was slightly higher than earlier report 
(Akajiaku et al., 2014). In certain region of india, people traditionally use dried tamarind fruit pulp together with the seeds for preventing the rancidity and to enhance the self-life of groundnut oil and coconut oil (Bhadoriya et al., 2011). Shankaracharya, (1998) reported that tamarind seeds are an important source of protein and valuable amino acids.

\section{Minerals content}

The result in Table- 2 showed that the calcium content of tamarind kernel flour was 109.25 percent. The calcium content is in comparison with the value reported by Bhattacharya et al.,
(1994). The magnesium and iron content of flour was found 247.51 and 11.37 percent, respectively. In present investigation, magnesium and iron content content of tamarind kernel flour were lower than that of an earlier report for roasted tamarind flour (Akajiaku et al., 2014).

The iron content seems to be lower when compared to that value reported by Ajayi et al., (2006) and Akajiaku et al., (2014). Thus, the variation of proximate composition and minerals content in tamarind kernel flour might be due to varietal difference, variation in agro-climatic conditions and different roasting conditions also.

Table.1 Proximate composition of tamarind kernel flour (\%, dry weight basis)

\begin{tabular}{|l|c|c|c|c|c|c|}
\hline \multicolumn{1}{|c|}{ Sample } & $\begin{array}{c}\text { Moisture } \\
(\mathbf{g})\end{array}$ & $\begin{array}{c}\text { Ash } \\
(\mathbf{g})\end{array}$ & $\begin{array}{c}\text { Fat } \\
(\mathbf{g})\end{array}$ & $\begin{array}{c}\text { Crude } \\
\text { protein } \\
(\mathbf{g})\end{array}$ & $\begin{array}{c}\text { Crude } \\
\text { fibre } \\
\mathbf{( g )}\end{array}$ & $\begin{array}{c}\text { Total } \\
\text { carbohydrate (g) }\end{array}$ \\
\hline $\begin{array}{l}\text { Tamarind kernel } \\
\text { flour }\end{array}$ & $7.65 \pm 0.01$ & $2.74 \pm 0.05$ & $5.7 \pm 0.11$ & $19.46 \pm 0.06$ & $2.32 \pm 0.06$ & $62.13 \pm 0.11$ \\
\hline
\end{tabular}

All the values are (Mean $\pm \mathrm{SD})$ of three observations

Table.2 Minerals composition of tamarind kernel flour (mg/100g, dry weight basis)

\begin{tabular}{|c|c|c|c|c|}
\hline Sample & $\begin{array}{c}\text { Calcium } \\
(\mathbf{m g})\end{array}$ & $\begin{array}{c}\text { Magnesium } \\
(\mathbf{m g})\end{array}$ & $\begin{array}{c}\text { Iron } \\
(\mathbf{m g})\end{array}$ & $\begin{array}{c}\text { Potassium } \\
(\mathbf{m g})\end{array}$ \\
\hline Tamarind kernel flour & $109.25 \pm 0.11$ & $247.51 \pm 0.07$ & $11.37 \pm 0.01$ & $1245.11 \pm 0.05$ \\
\hline
\end{tabular}

All the values are $($ Mean $\pm \mathrm{SD})$ of three observation

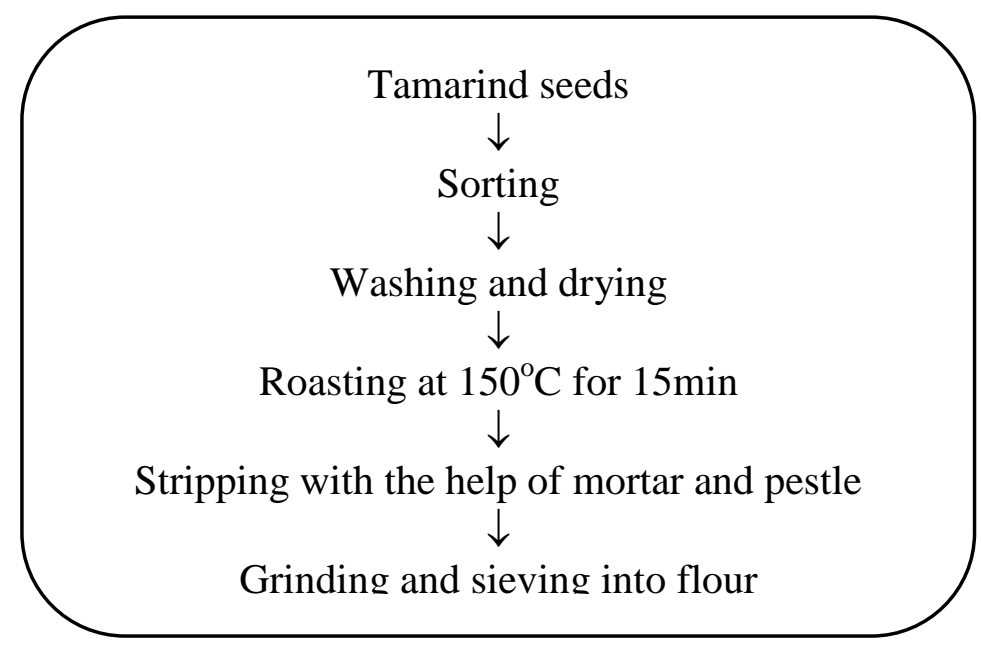

Fig.1 Flow Diagram of tamarind seed processing 


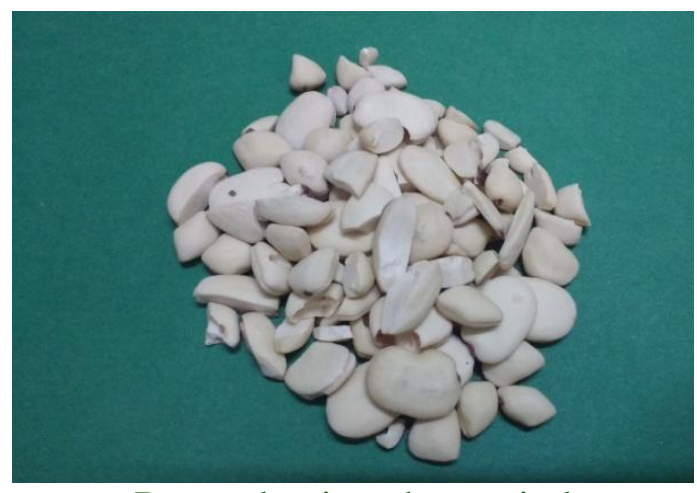

Roasted stripped tamarind

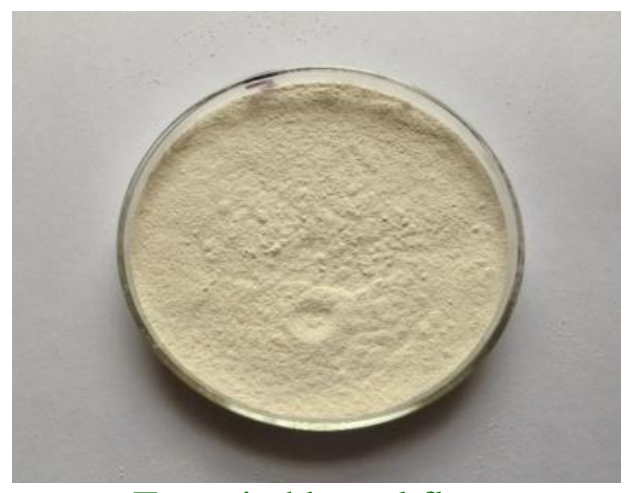

Tamarind kernel flour

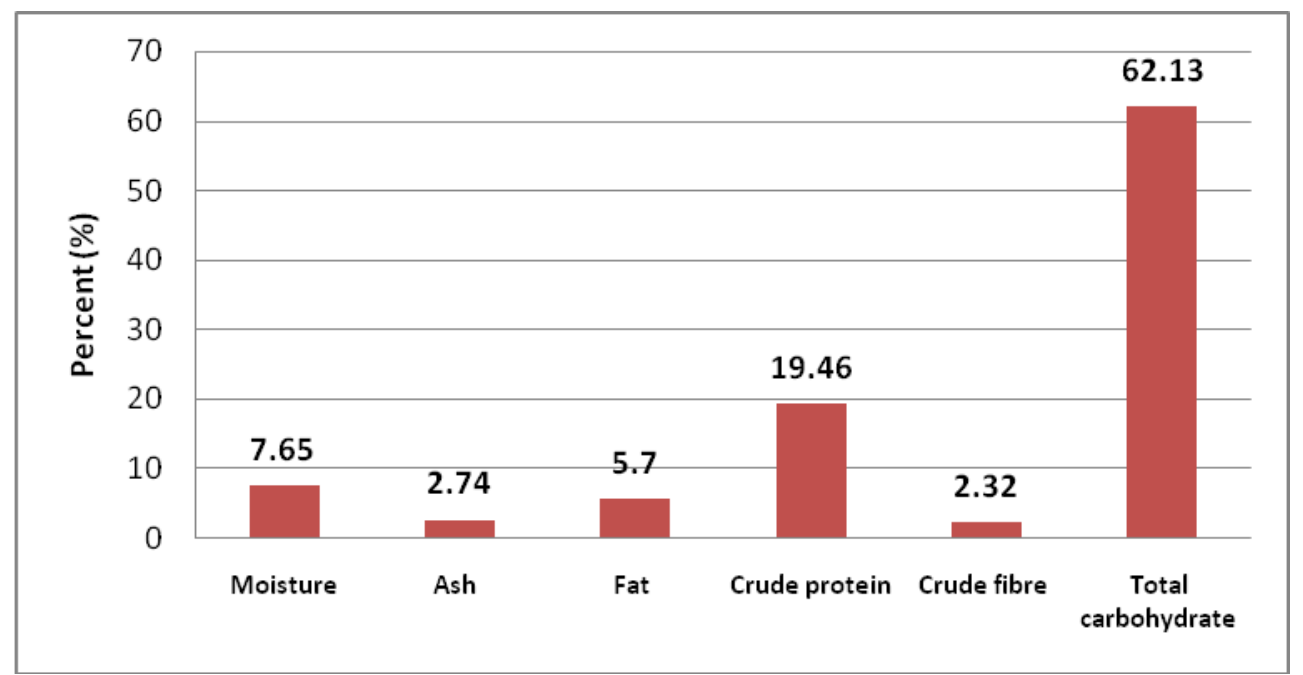

Fig.2 Proximate composition of tamarind kernel flour (\%, on dry weight basis)

The potassium content of flour was found 1245.11percent and it was the maximum among all minerals. Ajayi et al., (2006) and Akajiaku et al., (2014) also reported that the potassium is the highest element with the highest concentration in tamarind seed flour. According to Ajayi et al., (2006) the high concentration of potassium is nutritionally good considering the fact that potassium plays a principal role in neuro- muscular function.

Tamarind is a cheap and easily available plant. Tamarind seed, a by-product of tamarind pulp industries, is a typical underutilized material. The result indicated that tamarind kernel flour has good nutritional profile with high level of protein, lipid and some minerals. It can be incorporated into cereals flour in formulation of different food products. The utilization of tamarind seed as a protein ingredient in food will help reduce the over dependence on conventional protein supplements notably soybean and other common legumes.

\section{References}

Ajayi, I.A., Oderinde, R.A., Kajogbola, D.O., and Uponi, J.I. (2006). Oil content and fatty acid composition of some underutilized legumes from Nigeria. Food Chemistry. 99, 115-120

Akajiaku, L.O., Nwosu, J. N., Onuegbu, N.C., Njoku, N.S., and Egbeneke, C.O. (2014). Proximate, mineral and anti-nutrient composition of processed (soaked and roasted) tamarind (Tamarindus indica) Seed nut. Current Research in Nutrition and Food Science. 2(3):136-145. 
Bhadoriya, S.S., Ganeshpurkar, A. R., N, Jain, A.P. (2011). Tamarindus indica: extent of explored potential, Pharmacogn J Rev. 5 (9):73-81

Bhattacharya, S., Bal, S., Mukherjee, R. K., and Bhattacharya, S. (1994). Functional and nutritional properties of tamarind (Tamarindus indica) kernel protein. Food Chemistry. 49:1-9.

Caluw, E. D., Halamov, K., Damme, P. V. (2010). Tamarindus indica L.: a review of traditional uses, phytochemistry and pharmacology. Afrika Focus. 23 (1): 5383.

Duhan, A., Khetarpaul, N., and Bishnoi, S. (2002). Changes in phytates and $\mathrm{HCl}$ extractability of calcium, phosphorus and iron of soaked, dehulled, cooked and sprouted pigeon pea cultivar (UPAS-120). Plant Foods for Human Nutrition. 57:275-284.

Havinga, R. M., Hartl, A., Putscher, J., Prehsler, S., Buchmann, C., and Vogl, C. R. (2010). Tamarindus indica L. (Fabaceae): patterns of use in traditional African medicine. J Ethnopharmacol. 127 (3): 573-588.

Khairunnuur, F.A., Zulkhairi, A., Azrina, A., Moklas, M.A.M., Khairullizam, S., and Zamree, M.S. (2009). Nutritional composition, in vitro antioxidant activity and Artemia salina L. lethality of pulp and seed of Tamarindus indica $\mathrm{L}$. Extracts. Malays J Nutr. 15 (1). 65-75.

Kumar, C. S. and Bhattacharya S. (2008) Tamarind Seed: Properties, Processing and Utilization. Critical Reviews in Food Science and Nutrition.48:1-20.

Linda, O. A., Justina, N. N., Ngozika, C. O., Njideka, E. N. and. Egbeneke, C.O., (2014). Proximate, Mineral and Anti- nutrient Composition of Processed (Soaked and Roasted) Tamarind (Tamarindus indica) Seed nut. Current Research in Nutrition and Food Science. 2(3). 136-145.

Mohamed, H. A., Mohamed, B. E., and Ahmed, K. E. (2015) Physicochemical Properties of Tamarind ( Tamarindus indica) Seed Polysaccharides. $J$ Food Process Technol. 6:6-15.

Official methods of analysis, Association of Official Analytical Chemists (AOAC), 15th Edition, Washington DC, Washington, (2000).

Pugalenthi, M., and Vadivel, V. (2007). L- Dopa (1-3,4 Dihydrooxyphenylalanine): a non protein toxic amino acid in mucana pruriens seeds. Food. 13: 22-27.

Pugalenthi, M., Vadivel, V. and Janki, P (2007). Comparative evaluation of protein quality of raw and differentially processed seed of underutilised food legumes. Abrus precatorius, Livestock Res rural development. 19: 168-172.

Shankaracharya, N. B. (1998). TamarindChemistry, technology and uses: a critical appraisal. J. Food Sci. Technol. 35:193208.

Siddhuraju, P. (2007). Antioxidant activity of polyphenolic compounds extracted from defatted raw and dry heated Tamarindus indica seed coat. LWT-Food Sci Technol. 40: 982-990.

Siddig, E. 1. K., Gunasena, H.P.M., Prasa, B.A., Pushpakumara, D.K.N.G., Ramana, K.V.R., Vijayanand. P., Williams, J.T. (2006). Tamarind - Tamarindus indica L. Fruits for the future 1. Southampton Centre for Underutilized Crops, Southampton, UK, pp.188.

\section{How to cite this article:}

Gitanjali, Vishakha Sharma and Shashi Jain. 2020. Nutritional Properties of Tamarind (Tamarindus indica) Kernel Flour. Int.J.Curr.Microbiol.App.Sci. 9(05): 1359-1364. doi: https://doi.org/10.20546/ijcmas.2020.905.153 